\title{
The legal rights of workers and volunteers at the Edinburgh Festival Fringe.
}

\author{
MIDDLEMISS, $\mathrm{S}$.
}

2021

This author accepted manuscript is deposited under a Creative Commons Attribution Non-commercial 4.0 International (CC BY-NC) licence. This means that anyone may distribute, adapt, and build upon the work for non-commercial purposes, subject to full attribution. If you wish to use this manuscript for commercial purposes, please contact permissions@emerald.com 


\title{
The Legal Rights of Workers and Volunteers at the Edinburgh Festival Fringe?
}

\begin{abstract}
Against the background of the biggest arts festival in the world there have been some shocking findings recently about the treatment of performers and other workers at the fringe. ${ }^{1}$ This article will consider the type of treatment a significant number of fringe workers experience and how it might be dealt with under the law. The mistreatment of workers includes being: required to work excessively long hours, paid low wages or no wages, subject to sexual or street harassment, lookism, ageism or deprivation of other employment rights. What is unusual about fringe workers is they normally only work for a short time (often a maximum of two months). Also, in respect of performers and other theatre workers they might be inclined to work on a voluntary, unpaid basis in order to gain the necessary experience to kickstart their careers. Employers will often be theatrical promoters in charge of productions at a number of venues. This article will highlight the issues surrounding working at the fringe and identify the employment law issues for its workers. This will involve identifying likely breaches of legislation under the civil law and contract law by employers. Also, consideration of how the criminal law could apply to the treatment of workers will be undertaken. Finally, it will involve analysis of how the rights of fringe workers could be better protected. The findings and recommendations in this article will have application to any situation where someone is employed as a volunteer or worker in an artistic setting on a short-term basis.
\end{abstract}

\footnotetext{
${ }^{1}$ Workers might include those who: hand out leaflets, collect tickets, provide an administrative service or help with making and dismantling theatrical spaces.
} 


\section{Volunteers, workers or employees}

An estimated 30,000 male and female artists perform at the Fringe festival, across 3,500 shows. The precise status of workers at the fringe is important in determining their entitlement to employment rights so a definition of each of the above will follow alongwith an overview of their entitlement to employment law rights.

\section{Volunteers}

The distinction between volunteers and workers is important. This is because volunteers are not entitled to be paid or to have any significant employment rights beyond the right to; expenses, the protection of their health and safety and certain rights in respect of data protection. Whereas workers are entitled to a variety of employment rights. ${ }^{2}$ The Fair Fringe campaign argued strongly against fringe venues filling staff positions with volunteers. However, their latest report indicates the practice of doing so remains widespread. ${ }^{3}$ As the report argues, "You can't pay bills or buy food with experience, and volunteers don't have the same employment rights as workers and employees." 4 In a small number of cases, the courts have found that the terms of a volunteer's agreement with an organisation have amounted to a contract of employment. In these cases the volunteers were able to establish their entitlement to employment rights. Against this rather bleak background it might be surprising that volunteers are willing to undertake work on this basis. The main reason is undoubtedly that the experience gained working at the fringe can often be invaluable in persuading employers to offer someone future employment. The Advertising

\footnotetext{
${ }^{2}$ Middlemiss, S The Cost of Kindness: Voluntary workers and intern's rights under Employment Law? International Journal of Business Law (USA) (2014) Issue1 pp 110-127

${ }^{3} \mathrm{https}: / / \mathrm{www}$.fairfringe.org/2018ae and for 2019 report https://www.fairfringe.org/2019-advertising-exploitationreport

${ }^{4}$ Ibid p 8
} 
Exploitation report ${ }^{5}$ found that some employers justified using volunteers for financial reasons but the fair fringe campaign were unimpressed with that argument: "Some festival employers insist that if they paid their staff a proper wage their business would collapse. But the reality is that any business which can't afford to pay its staff properly cannot afford to operate. It is simply unacceptable, and wholly outwith the spirit of minimum wage legislation, to use volunteer labour to lower operating costs." ${ }^{6}$ Similar issues have arisen in the employment of interns in a business context although most interns seem to be better protected than volunteers. ${ }^{7}$ An intern is entitled to the National Minimum Wage if they count as a worker. ${ }^{8}$ They are also more likely to obtain a permanent position within the organisation in which they intern.

What specific rights do volunteer workers have? The employer could have a volunteer agreement in place which sets out the rights and duties of volunteers. It might cover things like; hours of work, the location of where the work will be carried out, the specific duties involved and any rights which they might have. They are normally entitled to the reimbursement of expenses they have incurred. This might cover travel costs (to and from work within Edinburgh) and subsistence costs but, would not extend to the cost of accommodation or associated expenses e.g. council tax or the cost of travel to and from Edinburgh to their actual home where it is outside the Capital. Under the Data Protection Act 1998, volunteers have rights in respect of their personal data. The organisation they volunteer for must ensure it complies with the eight Data Protection Principles. With respect

\footnotetext{
${ }^{5}$ Ibid

${ }^{6}$ Supra 3

${ }^{7}$ The Institute for Public Policy Research (IPPR) estimates that as many as one in five of all internships are unpaid but in the case of volunteers it is the vast majority.

${ }^{8}$ https://www.gov.uk/employment-rights-for-interns Exceptions to the rights are highlighted including volunteers
} 
to volunteers it is the duty of employers to keep their personal data up to date and the duty to ensure that data is only processed in accordance with lawful purposes that are most significant.

With respect of the National Minimum Wage Act volunteers are exempted so, they would certainly not be entitled to the minimum wage.

Under the health and safety legislation employers would be obliged to care for the safety of volunteers e.g. under section 3 of the Health and Safety at Work Act etc. 1974 and under certain Regulations e.g. duty to carry out a risk assessment under Regulation 3 of the Management of Health and Safety at Work Regulations. Under the common law it might be possible to argue that an employer had a duty of care towards volunteers under the law of delict. Employers are required by law to have employer's liability insurance, which offers protection if an employee is injured and the charity is negligent. In Unite the Union v Nailard ${ }^{9}$ the claimant maintained that she had been bullied and sexually harassed by union officials from the Union Unite. She claimed discrimination and harassment against Unite. She argued that Unite was vicariously liable for the actions of its officials, and was liable in relation to its own handling of her complaints. Although it was decided by the Employment Tribunal that the perpetrators were neither employees or agents of Unite but volunteers. Accordingly, they decided Unite were still vicariously liable for their actions. However, on appeal the Court of Appeal decided that the lay officials were acting as agents of the union and therefore the union was clearly liable for their actions. The importance of this decision is that employer can be vicariously liable for the wrongful acts of volunteers.

Vicarious liability typically places responsibility for an employee's actions or inactions with their employer. However, in recent years in England and Wales this concept has developed beyond

9 Case no. $3301974 / 2014$ 
traditional employment relationships and has been expanded to include activities by someone in a position akin to employment such as an office holder or a volunteer. This is subject to the activity in question having a close connection to their employment. Although these decisions are often not binding on the Scottish courts, the recent Supreme Court decision in Armes v Nottinghamshire County Council ${ }^{10}$ and other developments in the law of vicarious liability south of the Border would be considered persuasive should a similar case come before a Scottish judge or Sheriff.In Armes the court were asked to consider whether a local authority could be vicariously liable for the actions of a foster carer? They decided that they could be liable. This decision opens the doors for further expansion of vicarious liability by the courts which could easily extend to volunteers.

The Charity Commission ${ }^{11}$ which operates in England and Wales strongly advises charities to insure their volunteer s as well as employees. If employers have volunteers, working for them they can take out employer's liability insurance to cover them. Public liability insurance will not cover volunteers so it might be sensible for employers to take out a joint public liability and employer's liability insurance policy. While fringe workers are not charity workers similar considerations would apply so where individuals are carrying out work for an organisation and they come to harm the courts may decide that the fact that the workers at risk are volunteers makes very little difference. It is still a breach of the employers' duty of care.

Volunteers' right to bring discrimination claims on the basis of any of the characteristics covered in the Equality Act 2010 have been seriously circumscribed by the decision of the Supreme Court

10 (2017) UKSC 60 which held that local authorities south of the border could be vicariously liable for the unlawful actions of foster parents.

${ }^{11} \mathrm{https}$ //www.gov.uk/government/organisations/charity-commission. In Scotland the equivalent is the Office of the Scottish Charity Regulator (OSCR) https://www.oscr.org.uk 
in X v Mid Sussex Citizens Advice Bureau and another. ${ }^{12}$ The appellant was disabled, she had legal qualifications and worked with the respondent as a volunteer. She argued that as she was dismissed because of her disability and evenalthough she was working as a volunteer she had the right to bring a claim under the equality legislation. The Supreme Court disagreed on the basis that volunteers are not covered by UK domestic law or EU legislation in the form of the Framework Directive. ${ }^{13}$ The result of this is that volunteers cannot bring a discrimination claim on the basis of any of characteristic under the Equality Act 2010. Unfortunately, reliable statistical information on the number and distribution of volunteers across the fringe are not available at present. In the event that someone is not a volunteer they will be an employee or worker and their respective legal positions will be considered next.

\section{Employees ${ }^{14}$ or workers 15}

In general, there is a considerable difference between the employment rights available to each of these categories of persons in employment. However, in the case of fringe workers the employment rights available to employees and workers are remarkably similar. This is because of the shortterm nature of the employment of these workers and the fact that many of the rights that are only available to employees (and not workers) are dependent on periods of long service with the same employer e.g. two years' service for a claim for unfair dismissal or redundancy which do not tend

\footnotetext{
12 [2012] UKSC 59

${ }^{13}$ Council Directive 2000/78/EC establishing a general framework for equal treatment in employment and occupation 
to apply here. So, entitlement to long service rights does not apply to most fringe workers who are only employed for short periods. Therefore, it can be assumed that the rights being discussed apply to both employees or workers equally unless a difference exists which will be highlighted.

\section{Contractual rights}

Having said that employees and workers have the same employment rights in this context an exception this is the rights that are available under the contract of employment which only apply to employees. The likelihood is that there are no express terms in the contract (written or verbal) which protect fringe workers and in their absence employees will often need rely on implied terms for protection. There are a couple of implied terms which apply here.

\section{Implied terms}

This is an important, wide-ranging duty of the employer not to do anything that will jeopardise the position of trust and confidence between them and their employees. In the leading case of Malik v BCCI SA ${ }^{16}$ the House of Lords decided that the contracts of employees contain an implied term that employers would not, without reasonable and proper cause, conduct themself in a manner

${ }^{16}$ (1997) IRLR 462 
likely to destroy or seriously damage the relationship of confidence and trust between an employer and employee. Obviously having an organisational culture of harassment, bullying or discrimination or failing to protect workers from intimidatory behaviour of which they are aware would represent a breach of this implied term. The House of Lords in Malik extended the duty of trust and confidence to include a positive obligation on the employer to take all steps which are necessary to achieve the purposes of the employment. This could extend to protecting fringe workers from harassment, bullying or discrimination by colleagues and third parties.

Another implied term which is relevant here is employers' duty to take reasonable care for the safety of all their employees. There is an almost identical duty under the law of tort which employees are more likely to utilise. Employers are under a duty to provide a safe place of work, a safe system of work, safe plant and appliances and safe and competent fellow workers. If an employer fails to take reasonable care to protect an employee from a foreseeable physical or mental injury by failing to provide any of the above they could be found to have breached the duty of care. The standard of care is that of a reasonable employer and they will be expected to take more care of more vulnerable employees such as those that are young, inexperienced or disabled.

Under the implied duty to provide a safe working environment, employers are under an implied obligation to provide and maintain so far as is reasonably practicable, a working environment that is suitable for the performance of the contractual duties of employees. This duty may be breached, for example, where a fringe worker is being harassed or bullied at work by fellow employees or exposed to passive smoking. The remedy for a breach of any term in a contract is an action in the civil courts for breach of contract. The principal remedy under delict will be an award of compensation. 


\section{Equality Law}

\section{Discrimination}

Employees and workers have the same rights under the Equality Act 2010. There are various ways employers have been shown to discriminate against them in this context. The first of these is ageism where being of a particular age is an obstacle to gaining employment etc. The Fair Fringe report found that some festival employers openly advertised practices which could be seen as discriminatory on the basis of age. An example is when fringe job adverts exclude applications from persons under 18 for no justifiable reason (such as being unable to lawfully sell alcohol). The real reason for not taking on people under the age of 18 could be to avoid giving them the additional rights that very young workers have under the Working Time Regulations. For instance, workers under 18 are entitled to extra rest breaks, at least two consecutive days off per week (instead of 24 hours for older workers) and they cannot opt out of the regulations. Young workers are not usually allowed to work at night. However, exceptions can apply in some circumstances and they can work between the hours of 10pm and midnight.

Workers or employees with other characteristics may also suffer discrimination. Equity, the union that represents performers said it was inundated with complaints about sexual harassment from acts appearing at the fringe festival in 2019.

The Fair Fringe exploitation report found that some employers operate the practice of mandatory photo applications for Fringe jobs. They were critical of this as a recruitment practice because it 
allows employers to easily discriminate on the basis of appearance (lookism) age, gender, race or disability.

\section{Harassment}

As has been seen sexual harassment is a particular problem for performers at the fringe. Under section 26 of the Equality Act 2010 harassment is defined as 'unwanted conduct related to a relevant protected characteristic, which has the purpose or effect of violating an individual's dignity or creating an intimidating, hostile, degrading or offensive environment for that individual.' Under section 26 (4) (4) it is stipulated that tribunals in deciding whether conduct has the effect referred to in subsection (1)(b), each of the following must be taken into account (a) the perception of $\mathrm{B}$; (b)the other circumstances of the case and (c) whether it is reasonable for the conduct to have that effect. The relevant protected characteristics include, age, disability, gender reassignment, race, religion or belief, sex and sexual orientation. A person can also make a complaint of harassment even if it is not directed at them and they need not possess the relevant characteristic themselves. As seen the perception of the victim of harassment is very important and harassment can be deemed to have occurred even if the intention to harass was not present provided the recipient felt they were being harassed. As the legal definition of harassment refers to behaviour stemming from an individual engaging in prohibited conduct under the Act a tribunal can only hear claims that are brought on the basis that unlawful discrimination has occurred. The Fair Fringe campaign have encouraged fringe employers to do more to address the issue of harassment and emphasised their responsibility to provide a safe workplace which includes tackling sexual harassment by its customers, colleagues or managers. They also encouraged employers to create and implement a clear sexual harassment policy. Women working on shows at the Edinburgh 
Festival Fringe have reported facing sexual harassment on a daily basis while out promoting their performances, the BBC has been told. Some reported being groped, while others said lewd comments had left them feeling vulnerable. ${ }^{17}$ The actors' union Equity said it was receiving reports of "more and more" incidents each year. However perhaps surprisingly Police Scotland have reported they had not received any complaints of harassment. The lack of police involvement by victims is perhaps not surprising given that the victims might not equate the behaviour of the harasser with a breach of the criminal law. Also, the short-term nature of their employment may not incline them to take the incidents too seriously. However, where it involves unwanted physical touching or threatening behaviour it definitely is serious and a breach of the criminal law. Equity, the actors' union said many female performers had become accustomed to abuse but they encourage them to report all incidents to the police.

The Women and Equalities Commission (a parliamentary committee) has produced its report on Sexual Harassment in the Workplace. It made various recommendations for changing the law including extending sexual harassment protection to interns and volunteers. Very recently the Equality and Human Rights Commission published a technical note on Sexual Harassment and Harassment at Work. It claims to be the authoritative and comprehensive guide to the law and best practice in tackling harassment.

Another issue for fringe workers is often third party harassment. This is particularly the case where the worker is being harassed not by the people in the organisations they work for but by third parties such as members of the audience at a performance or members of the public in the street. It is now pretty certain that in most cases harassing conduct by third parties of workers will not be

\footnotetext{
${ }^{17}$ Hemmings, C Furst, J BBC Victoria Derbyshire programme 23 August 2019 Edinburgh Fringe female performers 'sexually harassed' https://www.bbc.co.uk/news/uk-scotland-49435737
} 
legally attributable to employers. The only option might be to bring an action against the perpetrator which might prove difficult. This has been the case since the Enterprise and Regulatory Reform Act 2013 repealed the third-party harassment provisions in section 40 of the Equality Act 2010. However, it has been argued that employees could still bring a claim for third-party harassment under the general harassment provisions in s.26(1) of the Equality Act 2010. This would involve the claimant arguing that the employer's inaction in allowing the harassment to take place is conduct related to a protected characteristic causing a hostile, intimidating or degrading environment. However, in the recent case of Unite the Union v Nailard the Court of Appeal held that this type of action has a very high threshold to meet. Namely, they needed to prove that the employer had a discriminatory motive for failing to take action in the face of complaints of thirdparty harassment in order for them to be liable. Where this is the case it might apply to harassment by members of the audience at the performance of a show. However, it is unlikely to apply when a worker is advertising a performance or leafletting in the street and is harassed by a member of the public because, what an employer can practically do in these circumstances to prevent or stop the harassment or protect the worker would be limited.

\section{The Protection from Harassment Act 1997}

This Act was originally enacted to deal with stalkers but has since broaden the types of cases that can be brought. There are both criminal and civil provisions. The Act does not specifically refer to volunteers but anyone found guilty of the offence of harassment ${ }^{18}$ of anyone (whatever their status) could face imprisonment and/ or a fine in England and Wales as well as civil action brought by the person subjected to harassment. In Scotland it would normally only be possible to pursue a

\footnotetext{
${ }^{18}$ As defined in section 1 of the Act
} 
civil action. If a volunteer were found guilty of harassment then they could face criminal proceedings as well as a civil action (although their status would be that of an individual, rather than a 'volunteer'). Similarly, if a volunteer were subject to harassment themselves then they (as an individual) would be covered by the legislation. Whether employers would be vicariously liable for sexual harassment perpetrated against volunteers by their customers or clients in the same way as for employees and workers is uncertain but seems likely in light of the Majrowski decision. ${ }^{19}$ The difficulties in successfully pursuing a case is given more detailed consideration below under street harassment which considers the legal protection for fringe workers from harassment outside the workplace by members of the public.

\section{Low Pay}

Research undertaken by the activist theatre company Power Play in $2018{ }^{20}$ found that men earn an average of 60 per cent more than women at the Fringe which is around seven times the national average. They also found the Edinburgh Fringe workers earned an average of just $£ 392.15$ for $t$ their work at the 2018 festival, covering a period of as much as 40 days (so that is around $£ 10 \mathrm{a}$ day). The research revealed that $38 \%$ of those surveyed were completely unpaid, with the average payment for those who did receive money standing at $£ 637.25$. The minimum amount an employer must pay increases annually but the current rate is $£ 8.21$ for workers aged 25 or over $£ 7.70$ for workers aged 20-24 $£ 6.15$ for workers aged 18-20 and $£ 4.35$ for workers aged under 18 .

\footnotetext{
${ }^{19}$ Majrowski v Guy's and St Thomas' NHS Trust [2006] UKHL 34 was a UK employment law case brought under the PHA 1997 where it was decided that that an employer could be vicariously liable under the Act for the harassment of an employee or worker by another worker.

$20 \mathrm{https} / / / \mathrm{www}$.powerplaytheatre.com/full-report
} 
Some workers at the fringe are not getting paid, others are not getting the national minimum wage despite being entitled to it, some are getting the national minimum wage but the vast majority are not entitled to the real living wage. The Fair Fringe charter encourages employers to sign up and pay workers the real living wage. Unfortunately, volunteers are specifically excluded from the National Minimum Wage Act 1998 so there is no entitlement to the national minimum wage for them. The Fair Fringe campaigners have identified that Fringe operators having being called out on the low levels of pay being given have found they are being far more secretive about the pay and conditions they are offering staff to work at the event. (a) If a worker does not receive his contractual entitlement to the NMW he they can take an action to the Sheriff Court for breach of contract. The penalty for not providing the NLW or NMW increased from $100 \%$ to $200 \%$ of the underpaid wages.

(b) They can also treat the shortfall as an unauthorised deduction and bring an action before an employment tribunal on that basis as a breach of Part 11 of the ERA Employment Rights Act 1996 (ERA 1996) (wages provisions). (c) The legislation provides protection to workers against being subjected to a detriment because they are enforcing their rights under the Act. (d) It will be automatically be unfair dismissal where the employer dismisses a worker because they are asserting their statutory rights. The Low Pay Commission have identified a tendency in recent times amongst a significant number of employers in the UK not to comply with the law in this respect and this is borne out by the findings of research into practices or employers at the festival fringe.

Shona McCarthy, the head of the Edinburgh Festival Fringe Society is critical of activists demanding fairer pay for fringe workers and warned that the campaign targeting poor treatment of 
workers in venues is threatening the event's future because some promoters and other employers cannot afford to pay the statutory minimum wage and certainly not the living wage .

\section{Working hours}

In October 2017, the Edinburgh Festival Fringe Society commissioned an independent survey of Fringe workers with the aim of developing a more detailed picture of the working lives of the many individuals who work at the festival. It highlighted that despite workers being entitled to a working week limited to 48 hours under Regulation 4 and at least 24 hours off per week under regulation 11 of the Working Times Regulations the survey showed that almost half of fringe workers (48 per cent) reported they worked more than 48 hours per week and around a third (31 per cent) said their average daily shifts lasted ten or more hours. More than a third said they were on a zero hours contracts. Given the casual or temporary nature of the employment and its short-term nature this figure seems surprisingly low. Some employers such as Summerhill ${ }^{21}$ and $\mathrm{C}$ Venues have committed themselves to stop using these contracts. As already mentioned, employers are not inclined to employ young workers because they have preferential rights under the Regulations. For example, there are special provisions in the Working Time Regulations for young workers who are under 18 but over compulsory school-leaving age. Young workers must not work more than eight hours a day and their maximum working week is limited to 40 hours a week. They are also entitled to 48 hours of consecutive rest each week and are entitled to the same amount of annual leave as adults. The Regulations apply to workers and this may also include volunteers. Where

\footnotetext{
${ }^{21}$ This is is a large venue near the Meadows in Edinburgh that presents theatre, cinema, music and live performances such as dance.
} 
these limits are breached there are various consequences for the employer. Under reg. 29 (1) an employer who fails to comply with any of the relevant requirements shall be guilty of an offence. There are various civil remedies that can apply to a worker including the right not to suffer a detriment. The report also cited several job advertisements in the fringe which required work schedules that contravened the Working Times Regulations and placed applicants in the position of having to waive their rights under the Regulations in order to be employed. It is clear that nonobservance by employers of the legal rules is widespread. Enhanced supervision and enforcement of criminal measures by the Health and Safety Executive and local government environmental health officers.

Also, civil claims by workers themselves should be encouraged and facilitated where appropriate.

\section{Recent Developments}

The plight of fringe workers experiencing a hard time at the hands of employers has not gone unnoticed. ${ }^{22}$ The Fair Fringe campaign has for around 3 years helped to protect fringe workers. One of the first actions of the campaign was to conduct a survey alongwith the Fringe Society. It was the biggest survey of Fringe workers ever carried out at the time. ${ }^{23}$ The survey in 2017 confirmed that there was a massive underpayment of workers with $49 \%$ of them earning less than $£ 7.50$ an hour which was the minimum wage at the time. Later the fair fringe campaign published

\footnotetext{
22 Hemmings, C Furst, J BBC Victoria Derbyshire programme 23 August 2019 Edinburgh Fringe female performers 'sexually harassed' https://www.bbc.co.uk/news/uk-scotland-49435737 The Guardian Edinburgh fringe 'must do more' to tackle sexual harassment Wed 21 Aug 2019 thttps:/www.theguardian.com/stage/2019/aug/21/edinburgh-fringemust-do-more-to-tackle-sexual-harassment

${ }^{23} \mathrm{https}$ //www.edfringe.com/learn/news-and-events/fringe-society-publish-results-of-venue-workers-survey
} 
its Advertising Exploitation report on 29 July 2018. ${ }^{24}$ It documented that discriminatory practices were widely used by companies at the Edinburgh Fringe to recruit staff and it caused controversy by highlighting the poor working environment for workers at the world's largest arts festival.

A number of key employers have been cited as using unfair practices in the report by the Fair Fringe campaign, including the Pleasance, Underbelly, Bound and Gagged, Zoo and The Space. The Fair Fringe campaign has also demanded that $C$ Venues one of the largest promoters at the fringe be banned from the official festival programme. This was in response to their finding that their financial model was built on exploitation, underpayment and overworking of staff. ${ }^{25}$

Since the 2018 exploitation report came out the campaign has found that problems of blatant exploitation and poor employment rights have not only persisted but have become less transparent. One aspect of lack of transparency is that employers have become far more secretive about the pay and conditions their workers receive.

The Fair Fringe campaign has set out to raise consciousness about the treatment of workers at the Fringe and also to inform workers of their rights. In respect of the latter objective they have achieved this by hosting collective learning events aimed at educating workers about their rights at work and how to enforce them. They have also set up a charter for organisations to sign up to where signatories amongst other things make commitment to: paying their workers the living wage; providing equality rights for young workers and having an anti-harassment policy in place. 26

\footnotetext{
${ }^{24}$ https://www.fairfringe.org/2018ae and for 2019 report https://www.fairfringe.org/2019-advertising-exploitationreport

${ }^{25} \mathrm{https}$ ://www.fairfringe.org/c-venues-report

${ }^{26} \mathrm{https}: / / \mathrm{www}$.fairfringe.org/the-charter
} 


\section{Street Harassment}

This is a particular type of harassment that is not specifically covered by statute such as the Equality Act 2010. Despite its harmful nature and long-standing existence it has to date largely gone unchallenged. Street harassment covers a wide range of behaviour in different locations but, usually in public. In this context the behavior might include; being shouted at, cat-called or followed in the street, sexual rubbing or touching, rape threats, sexual assault and men exposing themselves in public. The following quote highlights the severity of the problem as follows: "Sexual terrorism is an apt description of street harassment. As a young woman you know it will happen, but you never know for certain when or how it will happen. This makes street harassment hard to define, and difficult to combat. Its insidiousness derives in large measure from its venue: the semi-private, semi-public everyday occurrence of walking, sitting, or standing along city streets, or other public spaces such as parks and shopping malls." ${ }^{27}$ There is no specific law against street harassment in the UK but there are laws (both criminal and civil) that could prohibit behaviour that might be considered harassment. In England there are a number of public order offences that could deal with harassment under the criminal law. ${ }^{28}$ Given that Edinburgh is the location where this behaviour takes place it seems appropriate to consider the Scottish legal position on street harassment.

\section{Legal Position in Scotland}

\footnotetext{
${ }^{27}$ Fogg-Davis, H A Black Feminist Critique of Same-Race Street Harassment Temple University's Conference on Black Civil Society in American Life September 2005

${ }^{28}$ Public Order Act 1986 Section 4A - Intentional harassment, alarm or distress (1)A person is guilty of an offence if, with intent to cause a person harassment, alarm or distress, he-(a)uses threatening, abusive or insulting words or behaviour, or disorderly behaviour, or (b)displays any writing, sign or other visible representation which is threatening, abusive or insulting, thereby causing that or another person harassment, alarm or distress.
} 


\section{Civil law}

Civil claims in relation to street harassment could be brought under the Protection from Harassment Act 1997. However, there are some legal hurdles that need to be overcome if a claim is to be successful. The Act established that an individual can bring a claim against the perpetrator if he or she can establish they have been subjected to a course of conduct (more than one incident) which amounts to harassment and which his harasser knew or ought to have known amounted to harassment of them. So, a single instance of harassment which is often the case in street harassment is unlikely to be covered by the Act. Another limitation of the civil claim is that it only available as a remedy for conduct which amounts to behaviour that is sufficiently serious as to constitute a criminal offence under the Act. This requirement limits the applicability of the Act to only the most serious kinds of harassment or bullying. ${ }^{29}$ This civil action applies in England and Wales as well. If the harassment happens in the street while the person is working (e.g. handing out advertising material or performing) it could represent sexual harassment under the Equality Act 2010. However, it is unlikely to be behaviour for which the employer could be liable. The decision that clarified the law was that of the Court of Appeal in Unite the Union v Naillard ${ }^{30}$ which provided welcome guidance on a notoriously tricky area of law. Their view was an employer could not be liable for harassment of an employee or worker by a third party unless the employer has been motivated by discrimination in failing to effectively tackle the behaviour. However, this leaves an obvious gap in the law and means that employees who suffer harassment at the hands of third parties are often unprotected.

\footnotetext{
${ }^{29}$ Conn v Council of City of Sunderland (2008) IRLR 324 see fuller discussion of this remedy in Middlemiss, S “Another nice mess you've gotten me into" employers' liability for workplace banter, (2017) International Journal of Law and Management, Vol. 59 Issue: 6, pp.916-938

${ }^{30}$ [2018] EWCA Civ. 1203
} 
The employer could also be in breach of their duty of care under the law of delict if the worker suffered significant physical or mental harm from the actions of third parties and they could have reasonably known about the risk to their workers and the likely consequences of the unwanted behaviour. This burden of proof would be difficult to satisfy unless there were some precedents in terms of previous complaints about a particular person or persons in general to underpin the claim.

Given the evidential issues surrounding civil claims this article will concentrate on possible responses to the behavior under the criminal law.

\section{Criminal law}

In the past in Scotland street harassment would most likely be treated as a breach of the peace provided it was sufficiently serious. While this is still an option changes in the definition of the crime ${ }^{31}$ and the introduction of statutory offences dealing with harassing behavior (considered below) has meant it has become a less popular option. With the introduction of the offences of threatening or abusive behaviour and stalking under the Criminal Justice and Licensing (Scotland) Act 2010 they have removed the need to treat harassment as the common law offence of breach of the peace. The first of these under section 38 states; "it is an offence for a person to behave in such a manner that a reasonable person would be likely to fear for the safety of any person on account of the behaviour, or be alarmed or distressed by the behavior. "It is likely that this definition would cover most forms of street harassment. Similarly, with respect to stalking which could be

\footnotetext{
${ }^{31}$ In Smith v Donnelly (2002) JC 65 the High Court of Justiciary set out a test of whether conduct constitutes a breach of the peace. They decided it would be limited to where conduct was severe enough to cause alarm to ordinary people and threaten serious disturbance in the community which presents as genuinely alarming and disturbing, in its context, to any reasonable person.
} 
established where the perpetrator is constantly following someone section 39 provides: that a person commits an offence, of stalking, where he or she stalks another person. This is where he or she engages in a course of conduct which causes someone to suffer fear or alarm. This applies where the perpetrator knows, or ought in all the circumstances to have known, that they are engaging in a course of conduct which would be likely to cause them to suffer fear or alarm. The problem with utilising the stalking offence is the course of conduct requirement (two or more instances) which does not apply in most instances of street harassment.

Victims of street harassment could seek a common law interdict ad interim which can be readily obtained in the Scottish Courts and the balance of convenience test applied by the judiciary ensures that writs are not too widely framed. An advantage of the common law interdict is that there is no requirement to prove a course of conduct. An interim interdict or interdict can be granted on the basis of a single incident. While interdicts have been superseded in part by non-harassment orders under the Protection from Harassment Act 1997, they still have a place in protecting victims of harassment. This is particularly the case when a power of arrest (for breach) has been attached to the interdict under the Protection of Abuse (Scotland) Act 1998. A victim of street harassment could also seek an Anti-Social Behaviour Order (ASBO) which is a civil order introduced under the Crime and Disorder Act 2001 and designed to protect the public from anti-social behaviour. The law on this is now contained in the Antisocial Behaviour etc. (Scotland) Act 2004. In terms of section 143(1) of the Act 'a person engages in antisocial behaviour if he or she acts in manner which causes alarm or distress or pursues a course of conduct that causes or is likely to cause alarm or distress to at least one other person who is not of the same household as them. ' 
The Sexual Offences (Scotland) Act 2009 creates several offences in the law of Scotland that deal with sexual assault or sexual harassment and some of these could apply to street harassment. Firstly, the offence of sexual assault under section 3 of the Act may include any non-consensual: sexual touching, any form of sexual activity (whether or not through clothing), ejaculation of semen or emission of urine/saliva onto a person for sexual purposes. Secondly sexual coercion under section 4 where someone coerces a person to be present during a sexual activity or coerces a person into looking at a sexual image. The latter of these seems more likely in the context of street harassment. Thirdly communicating indecently under section 7 where possibly sending a sexually explicit text message, message/posting on social media or email against the receiver's wishes. Fourthly the offence of sexual exposure under section 8 which involves the exposure of his or her genitals to someone purely for sexual purposes.

However, a more likely crime to be committed in the context of street harassment is indecent exposure. Indecent exposure is not covered by the Act but by the common law where it is regarded as a form of breach of the peace, shameless indecency or lewd practice. Indecent exposure will take the form of a sexual act towards another person and will be an offence if the other person does not, or cannot, lawfully consent. This charge can apply whether the victim is an adult or child. It is irrelevant whether the exposure takes place in public or in private.

In Scotland there is a specific upskirting offence, under the Sexual Offences (Scotland) Act 2010 however, there have been few prosecutions brought under the legislation. It has been suggested that the reason for this is that the legislation is flawed. ${ }^{32}$ Also, people can be prosecuted for sharing intimate images without consent under the Abusive Behaviour and Sexual Harm (Scotland) Act

\footnotetext{
32 The Scotsman Thursday, 9th August 2018, Leader comment: Scotland's upskirting law is not fit for purpose https://www.scotsman.com/news/politics/leader-comment-scotlands-upskirting-law-not-fit-purpose-267501
} 
2016 which does not require proof of a desire to cause alarm or distress. However, not all upskirting offences necessarily involve the sharing of the image. Scotland also has a range of offences which can be used to deal with online and offline abuse. These include threatening and abusive behaviour, stalking and improper use of a public telecommunications network, along with common law offences such as breach of the peace. The Protection from Harassment Act 1997 provides civil remedies in Scotland. Scotland has also introduced a new offence to deal with revenge pornography. The Abusive Behaviour and Sexual Harm (Scotland) Act 2016 makes it easier to prosecute for so-called revenge porn. The legislation makes it an offence to disclose, or threaten to disclose, an intimate photograph or film without consent.

There are range of criminal statutes that could potentially protect victims of street harassment. However, some of them need evidence of continuous behaviour on the part of the perpetrator which is unlikely because often the behaviour is opportunistic and one-off. Also, in many instances for the charges to stick they need the perpetrator to be caught in the act, witnessed by others (or cctv) and arrested at the scene. Given that street harassment often is of a one-off nature and happens in crowded places where the behaviour goes unnoticed by other members of the public or the police it is a very difficult crime to detect and prosecute. ${ }^{33}$ Another type of behaviour which has been reported as happening by Equity and others but for which there is no statistical data is sex for rent. This applies where landlords use their position to try and extort sexual favours from their tenants

\footnotetext{
${ }^{33}$ The police in England and Wales made the following statement about police procedure which is highly relevant: "The police and the Crown Prosecution Service have to make an assessment of the evidence available, whether it is witness, forensic or even hearsay. In circumstances where there is insufficient evidence, the decision may be taken to focus resources on those offences which are capable of being charged and prosecuted. There might be a number of reasons why no further action was possible. Some cases are just undetectable. However, cases can be reopened if more evidence becomes available." https://www.police.uk/about-this-site/faqs/\#large-proportion-of-no-action-taken
} 
in return for not collecting the rent. ${ }^{34}$ This is clearly a form of sexual harassment which could be unlawful under the civil law particularly under the Protection from Harassment Act 1997 and the Equality Act 2010. However, in the absence of any threatening or intimidating behaviour it is unlikely to be a breach of the criminal law statutes highlighted above. However, under housing law in Scotland if the harassment is being used by the landlord to get someone to leave a house then there could be remedies under the criminal law. For example, the victim could get a nonharassment order telling their landlord to stop harassing them or get a court order which will force their landlord to let them back into their home and/or pay them compensation. They can also claim damages for illegal eviction or for harassment which has led to them having to leave their home (although they cannot claim for damages if they have been allowed to move back into their home). ${ }^{35}$

\section{The Council's Response}

Following months of lobbying, Edinburgh City Council voted unanimously to support the Fair Fringe Charter the series of reforms and changes designed to make the Fringe a decent environment to work in. They've also adopted their own version, The Edinburgh Festivals Workers' Welfare Commitment, which ensures workers are paid at least the local government public sector living wage, place a ban on zero hours contracts and unpaid trial shifts, ensures that workers get $100 \%$ of tips and better protection from discrimination and employers are expected to introduce in their workplaces sexual harassment policies. The council have now made it part of their leasing

\footnotetext{
${ }^{34}$ Walker, A Abuse of power: Edinburgh Fringe workers being pressured into offering sex for rent The Scottish Sun 21 Aug 2019 https://www.thescottishsun.co.uk/news/scottish-news/4629654/edinburgh-fringe-festival-performersworkers-sex-accommodation/

${ }^{35}$ Under the Housing (Scotland) Act 1988, if someone is unlawfully evicted or harassed to the extent that they leave their home the court may award compensation. The amount of compensation would be based on the difference in value between the property with no tenant and the property when occupied.
} 
agreement that, if someone wants to use one of their publicly owned venues, they have got to pay the local government living wage which will help improve the conditions and wages of thousands of workers not just at the Fringe but at any time the venues are used.

\section{Conclusion}

Despite the shameful record of employment practices on the part of certain employers at the Edinburgh fringe there are some signs of positive action. Edinburgh's fifth largest employer in the hospitality business Summerhall, ${ }^{36}$ signed a union recognition agreement with Unite in 2018 and amongst other things agreed to promote the Fair Fringe Campaign and set up regular drop-in sessions for workers held at their venue throughout the Fringe to outline worker's rights. Also the Stand Comedy Clubs in Edinburgh, Glasgow, and Newcastle have recently agreed to sign up to the 'Fair Hospitality Charter set up by the Unite trade union ${ }^{37}$ and which will see their workers; receive an immediate pay rise to the living wage; move them onto minimum hour contracts and off zero-hour contracts and pay their transport home after $11 \mathrm{pm}$. Volunteers are particularly vulnerable and unprotected compared with workers and employees. Consequently the use of volunteers should be discouraged and one possible solution would be to re-classify volunteers at the fringe as workers for the purpose of employment rights. This could be done at a local level through a council by-law or at a more generic level for people working in the arts.

\footnotetext{
${ }^{36}$ A muli-media and arts space

${ }^{37}$ https://www.fairhospitality.org/
} 
The existing laws dealing with wages and working hours are probably adequate to deal with the problems identified. However, workers need to be better informed of their rights (see the example of Summerhall) and support should be available from advisers (appointed by the council?) to support workers in enforcement of their rights under the legislation. The role of the Health and Safety inspectors and environmental health officers to enforce the Working Time Regulations should be encouraged and enhanced.

Regarding street harassment what is needed is a combination of actions not just a change in the law. Fringe workers could be given personal alarms by their employer which are connected to the police and which could inform them when harassment is occurring. An advertising campaign against street harassment directed at potential victims but also members of the public would help with prevention and detection of the behaviour. The introduction of new legislation dealing with street harassment is required. This is needed more generally but would be of particular benefit to fringe workers. What would this law consist of? A combination of a civil and criminal actions that can be taken against the perpetrator. ${ }^{38}$ A carefully considered and well-structured definition that can be used to underpin both types of legal action. Also, it is important that both type of action could be taken against the perpetrator after only one incident has taken place for the reasons already given. ${ }^{39}$ The provision of extra police officers on the beat in areas where this behaviour is likely to happen would also be necessary for enforcement of the criminal aspects of the new legislation.

Members of the Scottish Parliament (MSPs) have failed to fully address the issues identified in this article. Employment law remains reserved to the UK Parliament so it would be difficult for

\footnotetext{
${ }^{38}$ Similar to the provisions in the Protection from Harassment Act 1997

${ }^{39}$ The option should be available of applying to the court for an interdict to stop the behaviour where it is repetitious (e.g. non-harassment order) and the power of arrest attached to the interdict when it is breached.
} 
them to make any changes to it (e.g. generally outlawing the use of volunteers). However, this does not affect their right to make changes to the criminal law which is a priority for victims of street harassment. Also, some of the practical changes mentioned could be introduced by the Scottish Parliament. 